\title{
Borrowing, the Outcome of Language Contact*
}

Paiman Hama Salih Sabir/ Scientific degree: Assist lecturer/MA in Applied Linguistics

University of Sulaimani/Faculty of Physical and Basic Education/School of Basic

Education/English department

This study which entitles "Borrowing, the Outcome of Language Contact" tackles one aspect of the current sociolinguistic phenomenon, which borrowing words by Kurdish speakers as the result of language contact.

Due to the development of technology, globalization, and easiness of transportation among different countries, languages come into contact, as the result words are borrowed from one language to another and especially from the donor language to the recipient one.

Since Kurdish language (as one of the world languages) is also been affected by the new trend of language contact, accordingly many words have been borrowed into all aspects of life.

For this purpose, the researcher tries to define borrowing or loan words, classify them depending on literature and identifies the major factors on borrowing words, finally, the researcher presents a number of tables within which she represents a vast number of borrowed words from English, adapted from a study that she has done on English loan words used by Kurdish people at visual media.

\section{Introduction}

Speech communities get into contact with others whether with speakers of the same language or other languages due to different needs, such as trade, travel, and economic exchange or scholarly exchange. Sometimes language contact occurs through historical events, such as invasions or even through wars. Taha (2006) points out in his study how loan words were borrowed with the entrance of the American troops, reporters, news broadcasters and journalists after the gulf war in Iraq.

As a result of language contact, different linguistic outcomes are resulted such as borrowing, interference, language shift, code mixing and code switching, structural diffusion, language creation and sometimes language death. This study is bird's eye view of borrowing as one of the linguistic outcomes of language contact.

\section{Language Contact}

Almost most of the languages in the world are subject of influence of language contact at one time or another. Different labels have been used to refer to phenomenon of language contact such as barbarism or foreign word and transcodic marker, since language contact has been analyzed from a variety of perspectives, (.Solé, 2003: 4). Languages have been in contact for thousands of years, at least when human kind started using more than a language and this linguistic phenomenon is everywhere, and as Thomson (2001: 11 ) points out "no evidence that any languages have develop in total isolation from other languages".

Language contact is defined as the "use of more than one language in the same place at the same time", (Ibid,2001: 1) Language mixture is considered as a creative, rule-governed process

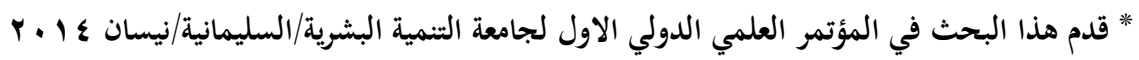


affecting all types of languages or even dialects in different degrees and forms in a way or another, such a mixture is not strange or atypical, but almost always has a role in the development of languages. Crystal (1992: 216) views language contact as a "geographical continuity or close social proximity between languages or dialects, so that a degree of bilingualism comes to exist within a community. The languages then begin to influence each other, such as by introducing loan words or making changes in pronunciation"

So, whenever speech communities communicate, it is obvious that they face difficulty to communicate, and for this reason there is a natural tendency to seek ways of bypassing the communicative barriers facing them, which can be overcome in different ways such as code switching or making use of each other's terms, words, lexemes,...etc.. Such a sort of language contact results in various types of linguistic out comes. Sometimes the outcome is a slight borrowing of vocabulary, or the creation of a new language like Pidgin and Creoles.

\section{The Outcomes of Language Contact}

As mentioned before, when languages come in contact, there will be various linguistic outcomes. (Thomson, 2001:30) points out that the most common result of language contact is change in some or all of the languages, at least one of the languages will exert some influence on at least one of the other languages

Outcomes of language contact include such mechanisms as language shift (in which speakers tend to shift from using a usual lower prestige variety or language to a higher prestige). , code switching (which includes alternation of two languages within a single sentence), code alternation mechanism of interference in which bilinguals use one of their languages in one set of environments and the other language in a largely different set of environments (Ibd:2001:261), language creation such as Pidgin and Creole, bilingual mixed languages, Structural diffusion or structural convergence which this can happen when languages are in extensive, long-term contact or even language death that happens when language shift involves the last remaining group of speakers of a language. But the major outcome is borrowing and since this study focuses on borrowing as an outcome of language contact,it will be give more concern as follows.

\section{Types of Language Contact}

Languages contact in various ways. Accordingly, different types of language contact are identified; the first type is called direct contact. In this type the speakers of one language turn up in the midst of speakers of another due to certain reasons such as invasion or immigration. The second type of language contact is labeled as indirect contact which is resulted from mediation of literature or nowadays thorough new technology such as TV, radio, internet, etc... (Thomason, 2001: 4).

There is another classification based on the sort of relationships between the languages affected which is termed as "natural borrowing" and "intimate borrowing". Furthermore, there is a sort of classification bases on the hierarchy of the speech varieties affected; accordingly two types of language contact are identified which is borrowing between national languages and dialect borrowing. Formal classification is another type which based upon the degree of modification of lexical units of the source language, (Capuz, 1997:82), which in turn leads to the typology between loanwords and loan translation.

The last type of classification is done on the bases of the linguistic level of the target/receiving language affected by the language contact mechanism, accordingly there is formal borrowing,which includes phonetic and graphic borrowing as it affects the form but not meaning, morphological borrowing, semantic borrowing, lexical borrowing, syntactic borrowing, phraselogical borrowing and pragmatic borrowing. 


\section{Borrowing}

When speech communities come into contact, they import features from the odd language to their native language. So, it can be stated that borrowing is an outcome of language contact .Sapir (2001: 2) points out that the simplest kind of influence that one language may exert on another is the "borrowing". Borrowing or loan words is defined differently by linguists. Simply it implies that one language takes linguistic elements(s) from another language and makes it as an inseparable part of the language in order to expand the languages vocabulary.

It is observed that borrowing occurs in both directions (i.e.) between the donor language and the recipient one, but Kemmer (2011: 1) points out that there is an

" asymmetry" that more words go from one side to another.

Linguists define borrowing differently. For Crystal (1992:46) borrowing means the "introduction of a word or some other linguistic features from one language or dialect into another". And for Mahwi (2010:143) borrowing refers to "the adaptive words that are derived by phonological or morphological phonotactics of a language in a way that suit the language system".

However, other linguists like Rendón (2008: 547) borrowing does not only include the borrowing of verbal linguistic elements, but it also includes non-verbal elements of communication such as gestures, gazes and movements since language use is not separable from movements between the speaker and the addressee, such as emblem for "ok".

It is believed that languages borrow those words from other languages which are not available in it, as Robins (1996:354) points out that "whenever and wherever there are contacts of any sort between the speakers of different languages, speakers will make use of words from other languages to refer to things, processes, and the ways of behavior, organizations, or thinking for which words or phrases were not available or convenient in their own language" ,cited in Yan Deng (2009:33).

\section{Classification of Borrowing}

Linguistics who work in the field of language contact, classify borrowed words or items differently. One of the well-known classifications is the one done by Haugen (1950), who distinguishes between loanwords, a process of borrowing in which there is a complete copy of the form and meaning of the borrowed item with loanblends, which are words of two parts: a copied part and a native part and the third class ob borrowed words which is labeled as loanshifts, where only the meaning is shifted.

Another taxonomy of borrowing is that is done by Myers-scotton (2002-239). For her borrowed words are of two categories cultural borrowings and core borrowings. The former includes words for new objects or non-object concepts, while the latter are words that duplicate already existing words.

Moreover, borrowed words are classified according to the borrowed aspect into phonetic borrowings, translation loans, semantic borrowings, and morphemic borrowing. Phonetic borrowing can be found in all languages. When a word is borrowed from a language, it is borrowed with its spelling pronunciation and meaning then undergoes assimilation. Sometimes the spelling, structure, meaning word paradigm of the borrowed words are also changed, or even the position of stress is influenced by the phonetic system of the borrowing language .Sapir (1921-3) in his discussion on the way languages affecting each other, states that "The borrowing of foreign words always entails their phonetic modification. There are sure to be foreign sounds or accentual peculiarities that do not fit the native phonetic habits. They are then so changed as to do as little violence as possible to these habits". There is another form of borrowing which is termed as "phonological borrowing", that occurs when adopts new sounds or changes already present sounds under the influence of another language that is contacted with, (De Kuthy,2001: 1).

Translation loans are word-for-word translation where the notion is borrowed from the donor language but it is expressed by lexical units of the recipient. Additionally, semantic borrowings are 
"such units when a new meaning of the unit existing in the language is borrowed", (На тему: 2011,12-13) and it occurs with relative languages which have common words but with different meanings. Furthermore, morphemic borrowing refers to the borrowing of affixes and finally there is syntactic borrowing.

\section{Factors on Borrowing}

There are different factors that affect borrowing; Internal or linguistic and external (social and psychological) factors. Within the linguistic factors is the nature of relationship between these languages such as the typological relationships Haspelmath (2008:11) refers to this factor as "structural compatibility" which has been invoked as explaining resistance to borrowing. .Weinreich (1953:3) is in the view that borrowing is only possible between structurally similar languages. And among the external or social factors such as the duration and the power of contact between the languages Haspelmath $(2008,10)$ points to this factor as a main factor and refers to it as "widespread bilingualism" and is often labeled as "intensity of contact". Genealogical relatedness is another external factor which implies that related languages are more likely to borrow from each other.

Moreover, the size and the power or language domination of a language is also is called language prestige. It is worth mentioning to state the various relationships are held between languages when they come into contact in contact situations. De Kuthy (2001: 5) states that if "If both groups are of equal prestige (neither is dominant over the other), then the languages enter into a similarly egalitarian relationship (called an adstratal relationship)" in this case borrowing occurs both directions, but if "If one groups is dominant over the other, then the language of the dominant group is the superstratum language, accordingly borrowing occurs from the superstratum language to the substratum one than the reverse, (Ibid, 2001:5). .

It is sometimes claimed that different cultures have different views towards borrowing, a behavior that is known is purism which explains the number of the borrowed words in the language. In this concern, Sapir (1921:2) points to the resistance to the borrowing of words, he states that " the psychological attitude of the borrowing language itself towards linguistic material has much to do with its receptivity to foreign words" . Onysko ( 2004:59-64) found two reasons for borrowing English words into German, which are semantic motivations when new products and inventions are accompanied by their basic English words and emotive as English has the modernity, hip and educated image.

There are also historical factors that also have a major role in borrowing. Ngom (2002:46) states this fact that "in the same manner that the statistical comparison of borrowings between languages reveals the nature of the past and present relationships between communities, the examination of the semantic fields of loan words shows the domains of contact and influence between communities".

In her study, Sabir (2013: 394) points to some factors that lead most Kurdish speakers to borrow and use English loan words, such as modernity of English language and better image, length of the native Kurdish terms as compared to the English ones, flexibility of use, and sometimes loanwords are used by some people to show off or to fill the lexical gap in the language.

\section{Borrowing in Kurdish Language}

Kurdish language like any other language has contacted with other languages from the history up to day such as Persian, Turkish, Arabic, English etc...Therefore the language has undergone change and different words have been borrowed from the languages which are genetically related or unrelated. Kurdish academy for language shows that in $(\% 13.8)$ of the words recorded in Wahbi and Edmonds' (1961) dictionary are loan words from different languages as Arabic, Persian, European and Turkish languages. Presently, due to the development of Kurdish society through technology that leads to the faster contact among societies and individuals, the advent of transportations means, globalization of English 
language...etc one observes that Kurdish language, like all other live languages, is affected by other languages, especially English and thousands of words have been borrowed to the language faster than before..

Media, in its all forms, as a major means of language contact have a great role in the introduction of new terms and linguistic elements to the language. Through which, different vocabularies related to different semantic aspects are rushed into languages.

Observing this linguistic phenomenon, Sabir (2013) conducted a study on the loanwords on visual media of Kurdish political programmes to recognize to which extend Kurdish politicians, announcers and editors make use of English loan words during these programmes. For this purpose, she analyzed a number of programmes in GK, NRT, KNN, ZAGROS and PAYAM satellite channels. She got results that of six hours of discourse (141) words have been used with the frequency of $(\mathbf{8 7 0})$. She analyzed the loans semantically into different fields , such as Political and Military Terms ,Technology terms, Administrative terms, Economic Terms, Ideology and beliefs, Activities and events, Jobs, titles and statues, scientific and social terms and Others or Miscellaneous . The following tables are samples of those loans from her study:

Table ( 1 ) :Political and Military Terms

\begin{tabular}{|c|c|c|c|c|c|c|}
\hline No. & In Kurdish & $\begin{array}{c}\text { Phonetic } \\
\text { transcription }\end{array}$ & English loans & Frequency & $\mathrm{E} / \mathrm{NE}$ & $\begin{array}{l}\text { Part of } \\
\text { speech }\end{array}$ \\
\hline 1. & تيروَرست & [tirorist] & Terrorist & 5 & $\mathrm{E}$ & N. \\
\hline 2. & تاكتيك & [taktik] & Tactic & 1 & $\mathrm{E}$ & N. \\
\hline 3. & لاستيكى & [lastiki] & elastic & 1 & $\mathrm{E}$ & N. \\
\hline 4. & ئدلألتهرناتق & [alterătiv] & Alternative & 1 & $\mathrm{E}$ & N. \\
\hline 5. & ئوّركان & [organ] & Organ & 1 & $\mathrm{NE}$ & N. \\
\hline 6. & يإز لهمان & [parlamān] & Parliament & 99 & $\mathrm{E}$ & N. \\
\hline 7. & كابينه & [kābina] & Cabinet & 59 & $\mathrm{E}$ & $\mathrm{N}$. \\
\hline 8. & بيلان & [pilān] & Plan & 3 & $\mathrm{E}$ & N. \\
\hline 9. & جينوّسايد & [cinosaid] & Genocide & 1 & $\mathrm{E}$ & $\mathrm{N}$. \\
\hline 10. & فيدر ال & [fidrăl] & Federal & 3 & $\mathrm{E}$ & adj. \\
\hline 11. & ئهجينده & [acinda] & Agenda & 3 & $\mathrm{E}$ & N. \\
\hline 12. & كروبֶ & [grŭp] & Group & 33 & $\mathrm{E}$ & N. \\
\hline 13. & فَيتّ & [vito] & Veto & 10 & $\mathrm{E}$ & N. \\
\hline 14. & يارت & [part] & Part & 5 & $\mathrm{E}$ & N. \\
\hline 15. & كوَنَكَِّس & [kongrěs] & Congress & 1 & $\mathrm{E}$ & $\mathrm{N}$. \\
\hline 16. & رزيّم & [rižěm] & Regime & 2 & $\mathrm{E}$ & N. \\
\hline 17. & ريقوّ ليوسن & [rivoliwŝn] & revolution & 1 & $\mathrm{E}$ & N. \\
\hline 18. & رِزَّم & [rižěm] & regime & 2 & $\mathrm{E}$ & N. \\
\hline
\end{tabular}




\begin{tabular}{|c|c|c|c|c|c|c|}
\hline 19. & ليّدهر لَّيس & [lyderlěs] & leaderless & 1 & $\mathrm{NE}$ & Adj. \\
\hline 20. & موّتتور & [motor] & motor & 1 & $\mathrm{E}$ & N. \\
\hline 21. & موّب & [mob] & mob & 3 & $\mathrm{E}$ & N. \\
\hline 22. & سيمينار & [symynar] & seminar & 1 & $\mathrm{E}$ & N. \\
\hline 23. & يَّو ليسى & [polisi] & policy & 5 & $\mathrm{E}$ & N. \\
\hline 24. & كوّنفيدر الْىلى & [konfedrałi] & Confederacy & 1 & $\mathrm{NE}$ & N. \\
\hline 25. & مين & [mǐn] & Mine & 5 & $\mathrm{E}$ & N. \\
\hline 26. & بوّ مباران ى كيميايى & $\begin{array}{c}\text { [bombărăni } \\
\text { kimiăı̌i] }\end{array}$ & $\begin{array}{c}\text { Chemical } \\
\text { bombardment }\end{array}$ & 4 & $\mathrm{E}$ & $\mathrm{N}$. \\
\hline 27. & موساد & [musăd] & Muss ad & 1 & $\mathrm{NE}$ & Adj \\
\hline
\end{tabular}

Table (2): Technology terms

\begin{tabular}{|c|c|c|c|c|c|c|}
\hline & In Kurdish & $\begin{array}{c}\text { Phonetic } \\
\text { transcription }\end{array}$ & English loans & Frequency & & $\begin{array}{l}\text { Part of } \\
\text { speech }\end{array}$ \\
\hline 28. & ويبسايت & [websăit] & Website & 1 & $\mathrm{NE}$ & N. \\
\hline 29. & ئينهرنهات & [itarnet] & Internet & 1 & $\mathrm{NE}$ & N. \\
\hline 30. & تهلهفزيون & [telefizyon] & Television & 3 & $\mathrm{NE}$ & N. \\
\hline 31. & ميديا & [midyă] & Media & 15 & $\mathrm{E}$ & N. \\
\hline 32. & كوّد & [kod] & code & 1 & $\mathrm{E}$ & $\mathrm{N}$. \\
\hline 33. & فليس بوك & [fais buk] & face book & 1 & $\mathrm{NE}$ & $\mathrm{N}$. \\
\hline 34. & زَوْرنالْ & Zhornal & journal & 1 & $\mathrm{E}$ & $\mathrm{N}$. \\
\hline 35. & ماسسج & [mesic] & Message & 9 & $\mathrm{E}$ & N. \\
\hline 36. & ستوديوّ & [stodyo] & studio & 1 & $\mathrm{NE}$ & N. \\
\hline 37. & سيناريوّ & [sinaryo] & scenario & 10 & $\mathrm{NE}$ & $\mathrm{N}$. \\
\hline 38. & تالهلهوَن & [talafon] & telephone & 1 & $\mathrm{NE}$ & N. \\
\hline
\end{tabular}

Table ( 3 ): Administrative terms

\begin{tabular}{|c|c|c|c|c|c|c|}
\hline & In Kurdish & $\begin{array}{c}\text { Phonetic } \\
\text { transcription }\end{array}$ & English loans & $\begin{array}{c}\text { Freque } \\
\text { ncy }\end{array}$ & $\mathrm{N} / \mathrm{NE}$ & $\begin{array}{l}\text { Part of } \\
\text { speech }\end{array}$ \\
\hline 39. & تيم & [tǐm] & Team & 1 & $\mathrm{E}$ & N. \\
\hline 40. & قونصليه & [qunsuya] & Council & 4 & $\mathrm{E}$ & N. \\
\hline 41. & بيلان & [pilăn] & Plan & 5 & $\mathrm{E}$ & N. \\
\hline
\end{tabular}




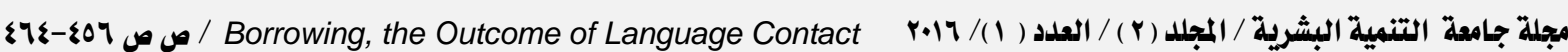

\begin{tabular}{|c|c|c|c|c|c|c|}
\hline 42. & يُروَّه & [proža] & Project & 19 & $\mathrm{E}$ & N. \\
\hline 43. & ليوّتَت & [post] & Post & 9 & $E$ & N. \\
\hline 44. & ديسيبلين & [disiplin] & Discipline & 1 & $\mathrm{E}$ & N. \\
\hline 45. & كوّ نفر انس & [konfrăns] & Conference & & $E$ & N. \\
\hline 46. & رايّورت & [raport] & Report & 3 & $\mathrm{E}$ & N. \\
\hline 47. & سيستام & [sistam] & System & 29 & $E$ & $\mathrm{~N}$. \\
\hline 48. & كادر & [kādr] & Cadre & 18 & $\mathrm{NE}$ & N. \\
\hline 49. & ليست & [list] & List & 2 & $\mathrm{E}$ & $\mathrm{N}$. \\
\hline 50. & فايل & [făil] & File & 1 & $\mathrm{E}$ & N. \\
\hline 51. & ي بروَّرَام & [progrăm] & Programme & 9 & $\mathrm{E}$ & N. \\
\hline 52. & سيكتار & [sektar] & Sector & 7 & $\mathrm{E}$ & N. \\
\hline 53. & كوّمسيوّن & [komsyon] & Commission & 2 & $\mathrm{E}$ & N. \\
\hline 54. & ئوّركانيك & [orgănik] & Organic & 1 & $\mathrm{E}$ & Adj \\
\hline 55. & كوّنكره & [kongra] & Congress & 8 & $\mathrm{E}$ & N. \\
\hline 56. & سانديكا & [sandikă] & Syndicate & 1 & $\mathrm{NE}$ & $\mathrm{N}$. \\
\hline 57. & كوّ ئهليزن & [koaližn] & Coalition & 1 & $\mathrm{E}$ & N. \\
\hline 58. & ريفوّرم & [reform] & Reform & 1 & $\mathrm{E}$ & N. \\
\hline 59. & كوّنتروّل & [kontroł] & Control & 5 & $\mathrm{E}$ & N. \\
\hline 60. & يُوّتوريتى & [otoriyi] & authority & 1 & $E$ & N. \\
\hline 61. & ئدكتيق & [aktǐv] & active & 1 & $\mathrm{E}$ & N. \\
\hline 62. & كهمبين & [kampǐn] & Campaign & 4 & $E$ & N. \\
\hline 63. & فر اكسيوّن & [fraksiyon] & Fraction & 1 & $\mathrm{E}$ & N. \\
\hline 64. & مانيفيست & manifsest & manifest & 2 & $\mathrm{E}$ & N. \\
\hline
\end{tabular}

Table (4): Economic Terms

\begin{tabular}{|c|c|c|c|c|c|c|}
\hline & In Kurdish & Phonetic transcription & English loans & $\begin{array}{c}\text { Freque } \\
\text { ncy }\end{array}$ & $\mathrm{N} / \mathrm{NE}$ & $\begin{array}{l}\text { Part of } \\
\text { speech }\end{array}$ \\
\hline 65. & بانـ & [bănk] & Bank & 1 & $\mathrm{E}$ & N. \\
\hline 66. & بودجه & [bŭdca] & Budget & 73 & $\mathrm{E}$ & $\mathrm{N}$. \\
\hline 67. & بيزنيس & [biznes] & Business & 13 & $\mathrm{E}$ & N. \\
\hline 68. & روَّل & [rol] & Role & 22 & $\mathrm{NE}$ & N. \\
\hline 69. & شانس & [acinda] & Agenda & 3 & $\mathrm{E}$ & N. \\
\hline 70. & ستر اكتور & [straktor] & structure & 1 & $\mathrm{E}$ & $\mathrm{N}$. \\
\hline 71. & ديكتاتور & [biznes] & Business & 13 & $\mathrm{E}$ & $\mathrm{N}$. \\
\hline 72. & كوّمبِانيا & [kompănyă] & Company & 4 & $\mathrm{E}$ & $\mathrm{N}$. \\
\hline
\end{tabular}




\begin{tabular}{|l|c|c|c|c|c|c|}
\hline 73. & [kwaliti] & Quality & 1 & E & N. \\
\hline 74. & كو اليتى & [kwantiti] & quantity & 2 & E & N. \\
\hline
\end{tabular}

Table( 5) :Ideology and beliefs

\begin{tabular}{|c|c|c|c|c|c|c|}
\hline No. & In Kurdish & $\begin{array}{c}\text { Phonetic } \\
\text { transcription }\end{array}$ & English loans & Frequency & N/NE & Part of speech \\
\hline 75. & ديموكر اسىى & [demokrăsy] & Democracy & 28 & $E$ & $\mathrm{~N}$. \\
\hline 76. & ئهريستوق قرات & [aristokrăt] & Aristocrat & 6 & $\mathrm{E}$ & N. \\
\hline 77. & ديكناتورر & [diktatori[ & Dictatorship & 11 & E. & N. \\
\hline 78. & سايت & [săit] & Site & 1 & $\mathrm{E}$ & $\mathrm{N}$. \\
\hline 79. & سيمّوكرات & [soŝyăl democrăt] & Social democrat & 4 & $\mathrm{E}$ & N. \\
\hline 80. & ريفر اندوّم & [rifrăndom] & Referendum & 3 & $\mathrm{E}$ & N. \\
\hline 81. & نازيزم & [năzizm] & Nazism & 1 & $\mathrm{NE}$ & $\mathrm{N}$. \\
\hline 82. & ديكتاتورى & [diktător] & Dictator & 1 & $\mathrm{E}$ & $\mathrm{N}$. \\
\hline 83. & ئايديا & [ăidyă] & Idea & 3 & $\mathrm{E}$ & N. \\
\hline 84. & قُيزن & [vižn] & Vision & 1 & $\mathrm{E}$ & N. \\
\hline 85. & توّتاليتاريزم & [totalitălitărizm] & Totalitarianism & 1 & $\mathrm{E}$ & $\mathrm{N}$. \\
\hline 86. & ناسيو ناليست & [nasyonlist] & Nationalist & 1 & $\mathrm{E}$ & Adj. \\
\hline 87. & فه يلسسوف & [Failasŭf] & Philosopher & 2 & $\mathrm{E}$ & N. \\
\hline 88. & فيدر ألَى & [fedrăl] & Federally & 11 & $\mathrm{E}$ & $\mathrm{Adv}$ \\
\hline 89. & ليير الّ ل ل ل & [librăł] & Liberal & 8 & $\mathrm{E}$ & Adj. \\
\hline 90. & ستالينى & [stalini] & Saltiny & 1 & $\mathrm{NE}$ & Adj \\
\hline 91. & توّتاليتاريان & [totalitarian] & totalitarian & 1 & $E$ & Adj. \\
\hline 92. & ديموكر اتى & democraty & democracy & 5 & $\mathrm{E}$ & N. \\
\hline 93. & ميّنتاليتى & [mentality] & mentality & 3 & $\mathrm{E}$ & N. \\
\hline 94. & ريياهبليكانيزم & [ripablikanizm] & republicanism & 1 & $E$ & $\mathrm{~N}$. \\
\hline 95. & ميّنتال & [mental] & mental & 1 & $\mathrm{E}$ & Adj. \\
\hline 96. & نازى & [nazi] & Nazi & 1 & $\mathrm{NE}$ & N. \\
\hline 97. & فاثيزم & [faŝizm] & fascism & 2 & $\mathrm{NE}$ & N. \\
\hline 98. & سبّكيو لهيزم & [sěkyularizm] & secularism & 3 & $\mathrm{E}$ & N. \\
\hline 99. & لوّجيَ & [locik] & logic & 1 & $\mathrm{E}$ & N. \\
\hline 100. & ئايديوّلوّوجى & [aidyoloci] & ideology & 3 & $\mathrm{E}$ & N. \\
\hline 101. & ميّنتنالْ & [mental] & mental & 1 & $\mathrm{E}$ & Adj. \\
\hline 102. & سيّكيولَلمر & [sekyula] & secular & 2 & $\mathrm{E}$ & N. \\
\hline
\end{tabular}

\section{Conclusion}

Though languages have different methods of increasing its vocabulary, but the major one remains the basic, which is called "borrowing". Borrowing is one of the linguistic outcomes of language contact and is found in all languages. Kurdish language like all other languages got and gets contact with other varieties; as a result various words from different languages rush into the language. Some of the words are borrowed as they are without change but others undergo certain changes, whether phonological, morphological...

Borrowing mechanism occurs due to different factors, such as historical, political, economic, language power or prestige and globalization.

\section{Bibliography}

- Crystal, D. (199). An encyclopedic dictionary of language and languages.UK: Blackwell

- De Kuthy, K, (2001). Language Contact. Linguistics. www.ling.ohio- state.edu/ kdk/201/autumn01/.../contact-4up.p

- Haspelmath, M.(2008) Loanword Typology: Steps Toward A Systematic Cross- Linguistic Study Of Lexical Borrowabilty. Berlin: Mouton De Gruyt. 
- На тему, (2011), Актуальні проблемиграматики, лексикології та стилістики основної іноземної мови〉.Томіна АльонаОлександрівна

- Haugan, E. (1950). The Analysis of Linguistic Borrowing. Language: Vol. 88, No. 1.Linguistic Society of America

- Kemmer,Z. (2011).Loanwords (Major Periods Of Borrowing In The History English).Http://Www.Ruf.Rice.Edu./ Kemmer/Words/Loanwords. Htl

- Rendón, J. 2008. Typollogiicall and Sociial Constraints on Language Contact. VOLUME I, ACADEMISCH PROEFSCHRIFT

- Mahwi, M. (2010).Morphology and Component -interaction. university of Sulaimani: Sulaimani.

- Ngom, F. (2002). Linguistic Borrowing as Evidence of the Social History of the Senegalese Speech Community. International Journal of Sociology of Language, 158, 37-51

- Onysko, A. (2004). Anglicisms in German: from iniquitous to ubiquitous: English Today, Sapir, 1921 Language: An Introduction to the Study of Speech. Harcourt Brace \&Company: US

- Sabir P.S.(2013) Increasing the Use of English Loan Words in the Performance of Kurds in Political Programmes at Visual Media.Iraq:/Kurdistan Region Journal of Zankoi Sulaimani/NO.40 (part B)

- Sapir, 1921 Language: An Introduction to the Study of Speech. Harcourt Brace \&Company: USA

- Solé,M,G.(2003). Language Contact Phenomena in Catalonia: The Influence of Catalan in Spoken Castilian. Selected Proceedings of the First Workshop on Spanish Sociolinguistics. Cascadilla Proceedings Project

- Taha, T.A (2006). College Students Evaluative Reaction TO Arabic Loanwords Used in the Context of the Iraq War. Education; Fall 2006; 127, 1; ProQuest Education Journals

- Thomason, Sarah G. 2001. Language Contact: An Introduction. Edinburgh: Edinburgh University Press

- Weinreich .U. (1953) language in Contact: findings and problems. The Hague: Mouton

- Yan, Y and Deng, T. (2009). On Chinese Loan Words from English Language. English Language Teaching, voll.2, NO.4 :China

\section{APPENDIX}

\section{Abbreviations}

Adj. =adjcetive

\section{$\mathrm{E}=$ equivalent}

\section{GK=gali Kurdistan}

KNN=Kurdish news network

NRT=Nalya Radio and TV.

\section{$\mathrm{NE} \mid=$ non-equivalent}

\section{N.=noun}

